ISSN (Online) 2710-3315

https://doi.org/10.20535/EHS.2021.233416

УДК 550.4

\title{
ЛІСОВІ ПОЖЕЖІ, ЯК ФАКТОР ЕКОЛОГІЧНОЇ НЕБЕЗПЕКИ (ГЕОХІМІЧНИЙ АСПЕКТ)
}

\author{
Н.О. Крюченко, Е.Я. Жовинський \\ Інститут геохімії, мінералогії та рудоутворення імені М.П. Семененка НАН України, \\ пр. акад. Палладіна, 34 Київ, 03680, Україна \\ e-mail: office.igmr@gmail.com
}

Актуальність теми. Пожежі - головний екологічний фактор, що впливає на цілий комплекс природних властивостей, що визначають стійкість екосистем і біоценозів. За 100 років середньорічна температура в Україні зросла на два градуси. Через зміни клімату природні зони зсуваються: збільшується площа степу, а лісів і лісостепу зменшуються. Підвищення температури по всій планеті призводить до різких змін погоди і екстремальних явищ. Через це природні системи стають уразливими. Найбільш пожежонебезпечні - хвойні молодняки i середньовікові насадження на Поліссі. Важливо розрізняти тип пожежі - верхова чи низова. При верховій пожежі гине вся рослинність і знешкоджується органіка грунту. Верхові пожежі $\epsilon$ найбільш потужним фактором змін в рослинному покриві. В той час, низові пожежі призводять до вигорання лісної підстилки, зміні фізико-хімічних умов середовища, що також може спричинити зміни рослинного трав'яного покриву.

Крім вигорання лісу важливим фактором екологічного стану територій є геохімічна складова грунтів, що відповідає за відновлення екосистем. В цьому і полягає актуальність досліджень.

Об'єктом дослідження є дерново-підзолисті грунти соснового лісу Житомирського Полісся території згарища (квітень 2020p.) і фонової території.

Метою роботи є дослідження впливу низової пожежі на перерозподіл елементів у дерновопідзолистих грунтах соснового лісу Полісся.

Наукова новизна і суть дослідження. Переважна кількість робіт щодо лісових пожеж стосується проблем викидів в атмосферу продуктів згоряння, що викликає викиди вуглекислого газу в атмосферу і виникнення «парникового ефекту» у вигляді несприятливих змін клімату. У продуктах горіння присутні токсичності сполуки, такі, як: оксиди вуглецю, сірки, азоту, вуглеводні різних класів, альдегіди, бензол і його гомологи та інше, а також солі і оксиди важких металів, які мають шкідливий вплив на живі організми і екологію в цілому. В останні роки з'явилися роботи, що відображають геохімічний стан грунту при лісових пожежах, але їх вкрай мало для розуміння процесів міграції та концентрації елементів [1]. В цьому сенсі геохімічна складова грунтів на території Полісся не розглядалась, що і становить новизну дослідження.

Методи досліджень. Вимірювання вмісту хімічних елементів в зразках грунту виконано за допомогою методу мас-спектрометрії з індукційно зв'язаною плазмою на аналізаторі Element2 (Німеччина) в Інституті геохімії, мінералогії та рудоутворення ім. М.П. Семененка НАН 
України. Аналізувалися наступні елементи - $\mathrm{Hg}$, As, Ba, $\mathrm{Mg}, \mathrm{Mn}, \mathrm{Mo}, \mathrm{Cd}, \mathrm{Co}, \mathrm{Cr}, \mathrm{Cu}, \mathrm{Pb}, \mathrm{Zn}$, $\mathrm{V}, \mathrm{Ni}$.

Кількісне визначення виносу або накопичення у грунтах хімічних елементів (\%) визначено наступним чином: $K_{c}=K_{3} \cdot 100 / K_{\phi}$, де $K_{3}$ - вміст елементів у грунтах згарища, $K_{\phi}-$ вміст елементів на фоновій ділянці.

Проведені термодинамічні розрахунки умов рівноваги природної системи "тверда фаза розчин" у багатокомпонентних системах виконували за програмою PHREEQC (міграції елементів, що враховує всі вірогідні форми, і всі конкуруючі реакції, що відбуваються в системі) з використанням методів термодинамічного аналізу і математичного моделювання. Для вирішення його автором розраховані форми міграції компонентів — неорганічні форми (у відсотках від суми молярних концентрацій всіх форм). Утворення різних форм в значній мірі залежить від фізико-хімічних параметрів системи "грунт - розчин" i, перш за все, від рН грунту. Змодельоване значення $\mathrm{pH}$ грунтових розчинів, що змінюється від 4 до 8 та прорахований можливий вміст різних форм міграції (у відсотках від суми молярних концентрацій всіх можливих форм) компонентів при температурі $25^{\circ} \mathrm{C}$.

Природні умови території досліджень. Рельєф місцевості являє собою рівнину, клімат континентальний: взимку середня температура $-7^{\circ} \mathrm{C}$, влітку $+19^{\circ} \mathrm{C}$. Грунти - дерновопідзолисті, кількість гумусу - 1-3\%, характеризуються кислою і сильно кислою реакцією (рН 4,0-5,5). Смність поглинання цих грунтів 15-20 мг·екв/100 г грунту. У складі поглинених катіонів - Ca, Mg, H, Al. В результаті цього грунти характеризуються слабкою насиченістю основами - 50-70 \%. Будова грунтового профілю наступна: $\mathrm{A}_{0}$ - лісова підстилка (3-5 см), $\mathrm{A}_{1}$ - гумусово-елювіальний горизонт, 1-2,5\% гумусу (5-7 см), $\mathrm{A}_{2}$ - підзолистий, горизонт білястого кольору (2 до 4 см), В - ілювіальний горизонт бурого кольору (5-10 см), поступово переходить в кору вивітрювання материнської породи - житомирські граніти і їх мігматити. На площі характерно близьке залягання кристалічних порід, що перекриваються воднольодовиковими піщаними відкладами та неогеновими четвертинними утвореннями - глинами строкато-барвистими.

Результати та обговорення. Нами розглянуто перерозподіл хімічних елементів у дерновопідзолистих грунтах соснового лісу на території Житомирського Полісся. Пожежа відбулася у квітні 2020 року, проби відібрано через місяць - у травні 2020р. Нами було опробовано дві ділянки досліджень - фонова та згарище на території Житомирського Полісся. Фонова ділянка обиралася за ідентичністю за ділянкою згарища і розташована за 3 км на південний захід від неї.

Грунтові зразки містять в собі як рослинні, так і мінеральні компоненти. Мінеральна частина при низовій пожежі $\left(400-600{ }^{\circ} \mathrm{C}\right)$ не може зазнати будь-яких кардинальних змін, але рослинні компоненти перетворюються в золу і сажу, а це спричиняє підвищення значень $\mathrm{pH}$ грунтів.

Першим етапом робіт була оцінка геохімічної поведінки хімічних елементів внаслідок горіння лісової підстилки. Оскільки мова йде про різку зміну температури від 10-20 до 400$900{ }^{\circ} \mathrm{C}$ було розглянуто фактор - температура їх кипіння, а значить, і випаровування [2]. Температура кипіння елементів має суттєві відмінності (рис. 1).

Хімічні елементи, що знаходяться в грунтах є необхідними поживними речовинами для рослин. Мікроорганізми розкладають органічну речовину грунтів і з часом повільно виділяють багато важливих поживних речовин [3]. Під час пожежі грунти зазнають різні незворотні перетворення при згорянні. Порогові температури визначаються як температури, при яких відбувається випаровування хімічних елементів. Ці порогові значення можна розділити на три основні категорії: чутливі - від 200 до $375^{\circ} \mathrm{C}$, помірно чутливі $-375-1100^{\circ} \mathrm{C}$ і відносно 
нечутливі - вище $1100^{\circ} \mathrm{C}$ (виходячи з того, що температура горіння деревного палива $1100^{\circ} \mathrm{C}$ ). Виходячи з цієї градації чутливим $\epsilon \mathrm{Hg}\left(356^{\circ} \mathrm{C}\right), \mathrm{As}, \mathrm{Cd}, \mathrm{Zn}-$ помірно чутливі та інші елементи - нечутливі. Необхідно відзначити, що такі метали, як цинк і мідь, які розглядаються в комплексі при вивченні геохімії грунтів, поводяться по різному. Так, температура кипіння цинку $907^{\circ} \mathrm{C}$, а міді $-2563^{\circ} \mathrm{C}$. Висока порогова температура кипіння міді, а також інших не чутливих елементів передбачає їх накопичення в грунті, тоді як чутливі і помірно чутливі легко випаровуються з органічної речовини при пожежі.

Під час пожеж відбувається знищення органічної речовини надгрунтових горизонтів і верхньої частини гумусового горизонту, а також склад гумусу грунтів після пожеж характеризується зменшенням кількості гумінових кислот, що призводить до збільшення $\mathrm{pH}$ грунтів, що важливо для розуміння ступеню надходження елементів у рослини. На фоновій ділянці $\mathrm{pH}$ склало 4,2-5,5, тоді як після пожежі - 5,5-7,2. Це залежало від двох складових щільності лісу, де було відібрано точкові проби та наявності глинистої складової. Як відомо, при надходження елементів до рослин відбувається переважно в іонних формах. За допомогою термодинамічних розрахунків умов рівноваги природної системи "тверда фаза - розчин" нами було розраховано значення $\mathrm{pH}$ грунтів, за якими надходження металів до рослин буде найменшим. Наприклад, при значенні грунту $\mathrm{pH} 5,5$ цинк мігрує у формі вільних іонів і $\epsilon$ доступним для рослин (до пожежі), а вже при 6 (після пожежі) переважає карбонатна форма, що робить елемент недоступним. Це ж стосується і інших металів. При суттєвій зміні рН грунтів відбувається поступова зміна рослинності на місцевості, де була пожежа.

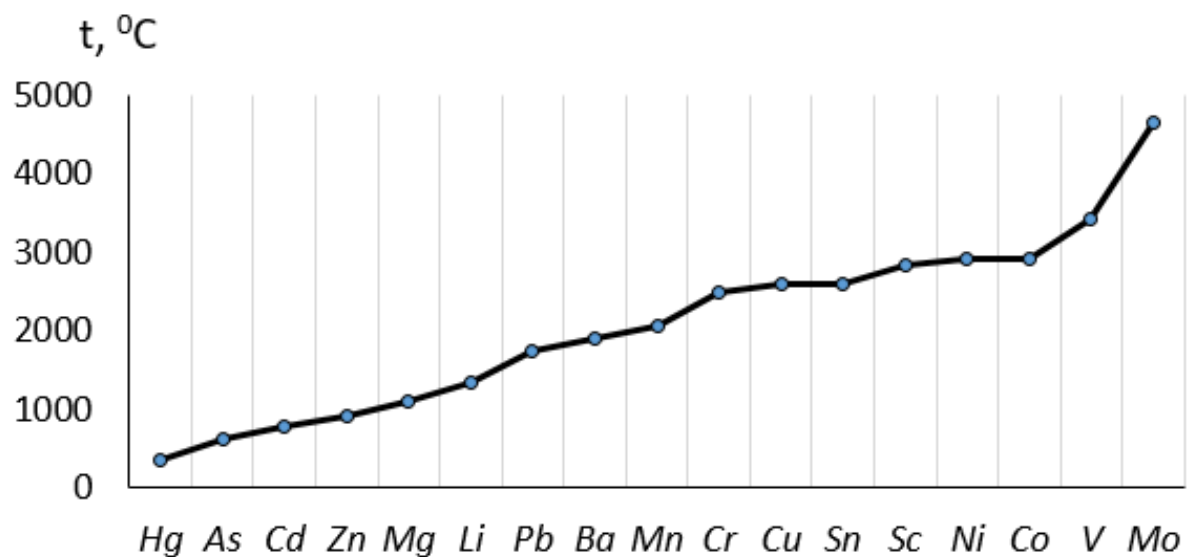

Рисунок 1. Графік температури кипіння хімічних елементів

3 метою визначення ступеню накопичення чи розсіювання хімічних елементів після пожежі розраховано відсотковий їх вміст, по відношенню до грунтів фонової території та побудовано діаграму (рис 2).

Виокремилися групи елементів, що накопичилися у грунті після пожежі, та ті, що розсіялися. Після пожежі у грунті встановлено групу металів, вміст яких виявився на $20 \%$ більший, ніж на фоновій ділянці - $\mathrm{Ba}, \mathrm{Ni}, \mathrm{Co}, \mathrm{Cu}, \mathrm{V}, \mathrm{Cr}$, та біля $5 \%$ - Pb, Mo, Mg. Після пожежі у грунти збідніли - Cd, Hg ( більше 20 \%) та Zn, Mo, As (5-10\%).

Висновки. Встановлено, що в результаті низинної пожежі на території Житомирського Полісся підвищується зольність грунтів, що призводить до підвищення $\mathrm{pH}-\mathrm{pH}$ грунтів фонової ділянки $-4,2-5,5$, тоді як горілої - 5,5-7,2. Зі зміною фізико-хімічних показників 
грунтового покриву пов'язано i різну поведінку окремих елементів. За результатами термодинамічного моделювання встановлено, що при значенні $\mathrm{pH}$ 5,5 грунту цинк мігрує у формі вільних іонів і є доступним для рослин (до пожежі), а вже при 6 (після пожежі) переважає карбонатна форма, що робить елемент менш доступним. Визначено ступінь накопичення чи розсіювання хімічних елементів після пожежі. Встановлено групу металів, вміст яких виявився на 20\% більший, ніж на фоновій ділянці - $\mathrm{Ba}, \mathrm{Ni}, \mathrm{Co}, \mathrm{Cu}, \mathrm{V}, \mathrm{Cr}$, та біля 5 \% - Pb, Mo, Mg; грунти збідніли - Cd, Hg ( більше 20 \%) та Zn, Mo, As (5-10 \%).

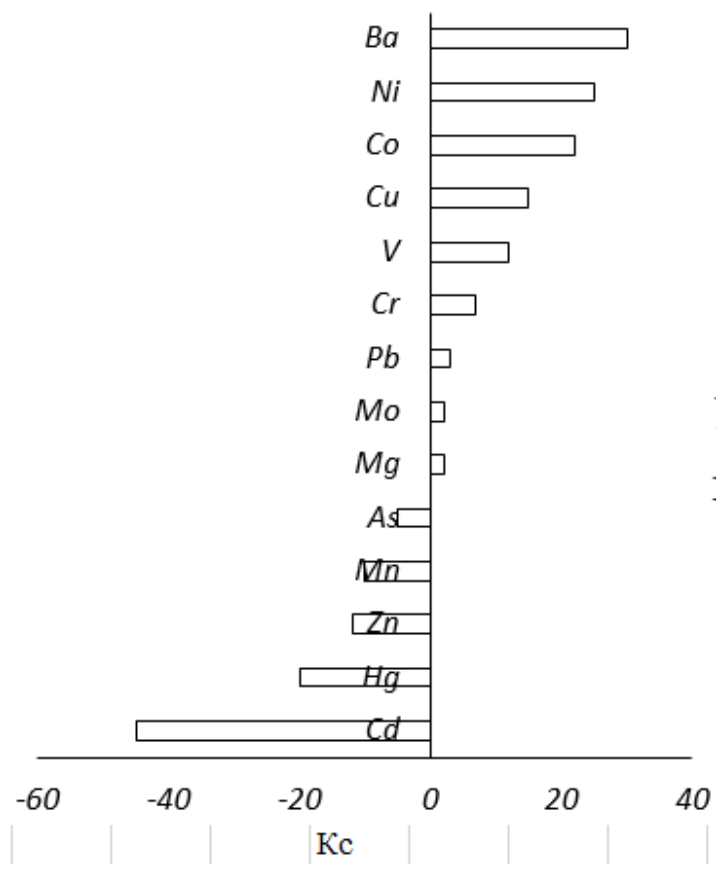

\section{Рисунок 2. Діаграма ступеню накопичення чи збіднення (Кс) грунтів на хімічні елементи після пожежі}

Зважаючи на те, що у грунтах лісових систем накопичуються радіоактивні та інші елементи, лісові пожежі можуть переводити депоновані в компонентах лісової екосистеми потенційно небезпечні хімічні елементи в активну летючу форму, змінювати фізико-хімічні умови грунтів та види рослинності, чим представляти геохімічну загрозу.

\section{Література:}

1. Ю.В. Буц, Ю.О. Масто, Аналіз виникнення надзвичайних ситуацій пов'язаних 3 пожежами в природних екосистемах та їх залежність від метеорологічних показників, Людина і довкілля. Проблеми неоекології, Вип. 2(15), с. 52-57, 2010.

2. В.В. Писаренко, Справочник лаборанта-химика. М.: Высшая школа, 192 с., 1970.

3. Б.Л. Щербов, Лесные пожары - важный фактор рассеяния и концентрирования химических элементов в ландшафтах Сибири, Геология и минерально-сырьевые ресурсы Сибири, №3, с. 37-40, 2014. 